\title{
A Ferrocenophane-Based Diaminophosphenium Ion
}

\section{Weller, Stefan}

2019-12-23

Weller , S , Schlindwein , S H, Feil , C M , Kelemen , Z, Buzsaki , D , Nyulaszi , L , Isenberg , S , Pietschnig , R , Nieger , M \& Gudat, D 2019 , ' A Ferrocenophane-Based

Diaminophosphenium lon ' , Organometallics , vol. 38 , no. 24 , pp. 4717-4725 . https://doi.org/10.1021/acs.organom

http://hdl.handle.net/10138/322380

https://doi.org/10.1021/acs.organomet.9b00701

unspecified

acceptedVersion

Downloaded from Helda, University of Helsinki institutional repository.

This is an electronic reprint of the original article.

This reprint may differ from the original in pagination and typographic detail.

Please cite the original version. 


\title{
A Ferrocenophane-based diaminophosphenium ion
}

\author{
Stefan Weller, ${ }^{a}$ Simon H. Schlindwein, ${ }^{a}$ Christoph M. Feil, ${ }^{\mathrm{a}}$ Zsolt Kelemen, ${ }^{\mathrm{b}}$ Dániel Buzsáki, ${ }^{\mathrm{b}}$ László \\ Nyulászi, ${ }^{*, b}$ Stefan Isenberg, ${ }^{c}$ Rudolf Pietschnig, ${ }^{*, c}$ Martin Nieger ${ }^{\mathrm{d}}$ and Dietrich Gudat*,a \\ ${ }^{a}$ Institut für Anorganische Chemie, University of Stuttgart, Pfaffenwaldring 55, 70550 Stuttgart, Germany \\ ${ }^{b}$ Department of Inorganic and Analytical Chemistry, Budapest University of Technology and Economics, and MTA-BME \\ Computation Driven Chemistry Research Group, Szent Gellért tér 4, 1111 Budapest, Hungary \\ c Institut für Chemie und CINSaT, Universität Kassel, Heinrich Plett-Straße 4034132 Kassel, Germany \\ ${ }^{\mathrm{d}}$ Department of Chemistry, University of Helsinki, P.O Box 55, 00014 University of Helsinki, Finland
}

\begin{abstract}
Reactions of P-chloro-1,3,2-diazaphospha-[3]ferrocenophanes with $\mathrm{ECl}_{3}(\mathrm{E}=\mathrm{Al}, \mathrm{Ga})$ under solvent-free conditions and with $\mathrm{Na}\left[\mathrm{Mn}(\mathrm{CO})_{5}\right]$ furnished salts featuring a ferrocenophane-based phosphenium cation or neutral phosphenium complexes, respectively. All products were characterized by spectroscopic studies. Single-crystal X-ray diffraction studies confirmed the ionic nature of the phosphenium tetrachloroaluminate and the structural analogy between the phosphenium complexes and Fischer-type carbene complexes. Distinct deviations in the conformation of the ansa-bridge suggest electronic stabilization of the electrophilic phosphorus atom by phosphorus-nitrogen $\pi$-interactions in the free cation and by phosphorus-metal $\pi$-bonding in the complexes. The observation of short intermolecular contacts in the crystalline phosphenium salt and its chemical behavior towards donor solvents attest the cation an unusually high degree of Lewis-acidity, which was confirmed by DFT studies and related to the presence of a rather large N-P-N angle. Computational studies indicate further that the free phosphenium cation exhibits a closed-shell electronic structure with a formal $\mathrm{Fe}(\mathrm{II})$ oxidation state and is thus a true analogue to ferrocenophane-based diaminotetrylenes.
\end{abstract}

\section{INTRODUCTION}

Even if the discovery of isolable salts of phosphenium cations Ia $\left(\mathrm{E}=\mathrm{P}^{+} \text {, Chart } 1\right)^{1}$ preceded that of stable carbenes Ib (E $=\mathrm{C}),{ }^{2}$ the realization of the isovalent relationship between both species has greatly fostered the development of phosphenium ion chemistry. ${ }^{3}$ This is in particular true for $\mathrm{N}$ heterocyclic phosphenium (NHP) cations IIa, IIIa $\left(\mathrm{E}=\mathrm{P}^{+}\right)$, which are formally isovalent to the well-known N-heterocyclic carbenes IIb, IIIb, but exhibit complementary chemical properties in behaving predominantly as electrophiles rather than nucleophiles. ${ }^{3 b-d}$ This dichotomy decreases, however, when comparing NHPs with the corresponding, truly isoelectronic silylenes IIc, IIIc $(\mathrm{E}=\mathrm{Si})$ or higher homologues thereof, all of which exhibit increasingly electrophilic properties. ${ }^{4}$

Chart 1. Generic molecular structures of carbenes and carbene analogues.

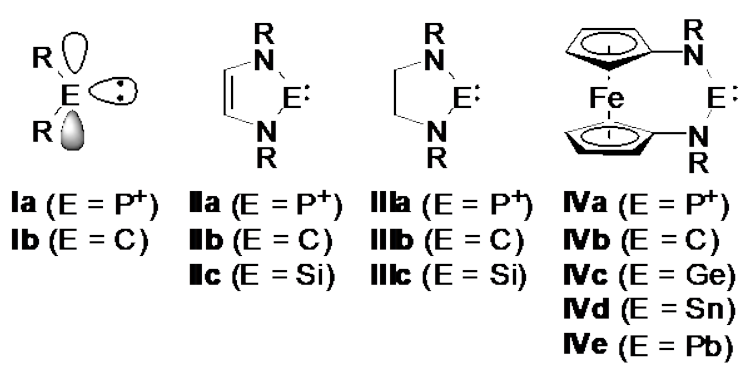

A class of cyclic diaminocarbenes and diaminocarbene homologues that has recently gathered attention are ferrocenophane-based tetrylenes $\mathbf{I V b}-\mathbf{e}^{5-7}$ in which the five- membered heterocyclic ring is formally replaced by a [3]ferrocenophane backbone. ${ }^{8}$ The combination of the subvalent main-group element with a redox-active ferrocene unit provides for an interesting chemistry that enabled, among others, the generation of unprecedented persistent tetrylene radical cations. ${ }^{5 c, 6 b}$ The cationic carbene derivatives feature a peculiar delocalization of the spin density between the ferrocene unit and the subvalent carbon atom, ${ }^{5 \mathrm{c}}$ while their heavier homologues exhibit a localized ferrocenium-type nature which does not compromise the tetrylene character. ${ }^{6 \mathrm{~b}}$ The redox noninnocence of the ferrocene-based carbenes is also conserved in transition metal complexes and enabled their use as redoxswitchable catalysts. ${ }^{5 a}$

The intriguing properties of the ferrocenophane-based tetrylenes IVb-e and their metal complexes raised our interest to explore the chemistry of the isoelectronic, but yet unknown, phosphenium ions IVa. Considering that reactions of diaminohalogenophosphines under halide abstraction or metathesis with suitable transition metal nucleophiles provide well established access routes to phosphenium ions and their complexes, ${ }^{3}$ we anticipated that the recently described P-halogeno-1,3diaza-2-phospha-[3] ferrocenophanes $\mathbf{1}^{9}$ might provide an entry point for our studies. We report here on validation of this hypothesis by conveying the syntheses of [3]ferrocenophanebased phosphenium ions and phosphenium complexes which constitute, to the best of our knowledge, the first examples of molecules with this specific architecture.

\section{RESULTS AND DISCUSSION}

Stable and persistent diaminophosphenium ions are usually accessed via cleavage of an anionic substituent from a neutral 
phosphine precursor. ${ }^{1,3}$ Halide ions are privileged leaving groups, and their abstraction can be accomplished by action of a strongly electrophilic halide scavenger (e. g. aluminum or gallium trihalide), or through condensation or metathesis with trimethylsilyl triflate $\left(\mathrm{Me}_{3} \mathrm{SiOTf}\right)$ or metal triflates (AgOTf, TlOTf), respectively. ${ }^{3,10}$ Monitoring the appropriate reactions of P-chloro-diazaphospha-[3]ferrocenophane $\mathbf{1 a}$ in various solvents (pure $\mathrm{CH}_{2} \mathrm{Cl}_{2}$ or its mixtures with pentane or $\mathrm{Et}_{2} \mathrm{O}$ ) by ${ }^{31} \mathrm{P}$ NMR spectroscopy, we found that condensation with $\mathrm{Me}_{3} \mathrm{SiOTf}$ did not yield any products qualifying as phosphenium ions, whereas metathesis with AgOTf and TlOTf suffered from low selectivity and reproducibility. Reactions with $\mathrm{AlCl}_{3}$ and $\mathrm{GaCl}_{3}$ seemed more promising, but the formation of side products arising from hydrolysis could not be avoided, and no isolable products were obtained. Attributing the synthetic problems to the presence of trace amounts of water even in rigorously dried solvents, we attempted accessing the target cations using a solvent-free protocol. Gratifyingly, we found that mechanical agitation of mixtures of solid 1a and stoichiometric quantities of $\mathrm{AlCl}_{3}$ or $\mathrm{GaCl}_{3}$ produced deep red oils or solids identified as the expected phosphenium salts $\mathbf{2 a}\left[\mathrm{AlCl}_{4}\right]$ and $\mathbf{2} \mathbf{a}\left[\mathrm{Ga}_{1.5} \mathrm{Cl}_{5.75}\right]$ (Scheme 1). ${ }^{11}$ Both species are highly sensitive towards air and moisture, but dissolved without decomposition in anhydrous $\mathrm{CH}_{2} \mathrm{Cl}_{2}$. Layering with pentane and allowing for mixing of the solvents by diffusion afforded $\mathbf{2 a}\left[\mathrm{AlCl}_{4}\right]$ as deep red, crystalline product which could be fully characterized, while the gallium salt remained oily and was only identified spectroscopically.

Scheme 1. Formation of [3]ferrocenophane-based diaminophosphenium salts $\left(\mathbf{R}=\mathbf{C H}_{2}{ }^{t} \mathbf{B u}\right)$.

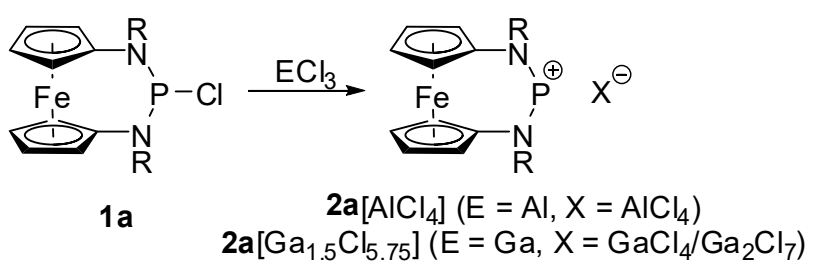

Solvent-free reactions of P-bromo-[3]ferrocenophane $\mathbf{1 b}$ (with $\mathrm{R}=\mathrm{SiMe}_{3}$ ) with $\mathrm{AlCl}_{3}$ or $\mathrm{GaCl}_{3}$ proceeded in a similar manner as those of 1a. Analysis of the resulting red oils by ${ }^{31} \mathrm{P}$ NMR spectroscopy revealed, however, that in this case a mixture of two phosphorus-containing species with chemical shifts of 300 and $312 \mathrm{ppm}$ had formed. Even if attempts to separation and unambiguous identification of any component remained unsuccessful, the observed chemical shifts support tentative assignment of one of the components as a phosphenium cation $\mathbf{2} \mathbf{b}^{+}$(Chart 2). We explain the formation of a second species as resulting from a side reaction involving dechlorosilylation of $\mathbf{1 b}$ and stabilization of the formed transient amino-iminophosphine as a complex $\mathbf{3 b} .^{12}$

Chart 2. Proposed molecular structures of $\mathbf{2 b ^ { + }}$ and $\mathbf{3 b}$.
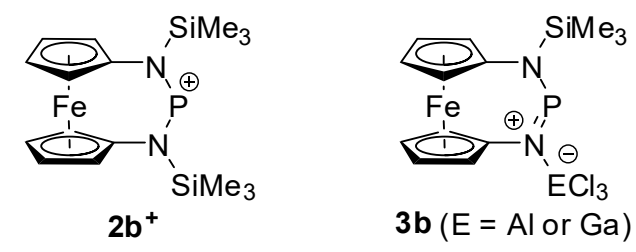

In accord with their postulated constitution as salts with the same cation, $\mathrm{CD}_{2} \mathrm{Cl}_{2}$ solutions of $\mathbf{2 a}\left[\mathrm{AlCl}_{4}\right]$ and $\mathbf{2} \mathbf{a}\left[\mathrm{Ga}_{1.5} \mathrm{Cl}_{5.75}\right]$ exhibit essentially identical ${ }^{1} \mathrm{H},{ }^{13} \mathrm{C}$ and ${ }^{31} \mathrm{P}$ NMR spectra and display the characteristic NMR signals of $\left[\mathrm{AlCl}_{4}\right]^{-}\left(\delta^{27} \mathrm{Al}\right.$ $103.7 \mathrm{ppm})$ or $\left[\mathrm{GaCl}_{4} / \mathrm{Ga}_{2} \mathrm{Cl}_{7}\right]^{-}\left(\delta^{71} \mathrm{Ga} 248.3 \mathrm{ppm}\right)$ anions, respectively. The phosphenium nature of the cation is alluded by a ${ }^{31} \mathrm{P}$ NMR chemical shift ( $\left.\delta^{31} \mathrm{P} 296 \mathrm{ppm}\right)$ that matches values reported for acyclic bis(dialkylamino)phospheniums $\left(\delta^{31} \mathrm{P} 264-313 \mathrm{ppm}^{3 \mathrm{a}}\right)$ while exceeding those of cyclic diazaphospholidinium (IIIa, $\delta^{31} \mathrm{P} 254-264 \mathrm{ppm}^{3 \mathrm{a}}$ ) and diazaphospholenium ions (IIa, $\delta^{31} \mathrm{P} 210-200 \mathrm{ppm}^{13}$ ), respectively. Moreover, the signal patterns in the ${ }^{1} \mathrm{H}$ and ${ }^{13} \mathrm{C}$ NMR spectra of $2 \mathrm{a}\left[\mathrm{Ga}_{1.5} \mathrm{Cl}_{5.75}\right]$ reflect the effective $C_{2 \mathrm{v}}$-symmetry expected for a phosphenium cation with a planar ferrocenophane ring. We interpret minor deviations between the ${ }^{31} \mathrm{P}$ chemical shifts of the aluminum and gallium salts $\left(\Delta \delta^{31} \mathrm{P}=0.2 \mathrm{ppm}\right)$ and the appreciable linewidth of the ${ }^{27} \mathrm{Al}$ NMR signal $\left(\Delta \mathrm{w}_{1 / 2}=16 \mathrm{~Hz}\right)$ as hints to the occurrence of ion pairing in solution. The large linewidth of the ${ }^{71} \mathrm{Ga} \mathrm{NMR}$ signal $\left(\Delta \mathrm{w}_{1 / 2}=2.3 \mathrm{kHz}\right)$ reflects dynamic exchange between $\left[\mathrm{GaCl}_{4}\right]^{-}$and $\left[\mathrm{Ga}_{2} \mathrm{Cl}_{7}\right]^{-}$.

Attempted dissolution of $\mathbf{2 a}\left[\mathrm{AlCl}_{4}\right]$ in other polar solvents than dichloromethane (e.g. THF or $\mathrm{MeCN}$ ) resulted inevitably in recovery of 1a via recapture of a chloride from the anion. We explain this behavior by assuming that, as in case of other highly electrophilic phosphenium ions, ${ }^{14}$ sequestering of $\mathrm{AlCl}_{3}$ through formation of an adduct with a donor solvent reverses the chloride transfer reaction shown in Scheme 1. It should be noted that the obvious stability of $\mathbf{2 a}\left[\mathrm{AlCl}_{4}\right]$ in $\mathrm{CD}_{2} \mathrm{Cl}_{2}$ seems at first glance in contrast to the difficulties encountered during the attempted preparation of this species by halide abstraction from 1a in the same solvent. However, in the light of previous reports, which had established that ion pairing increases the chemical stability of phosphenium ions in solution, ${ }^{15}$ the apparent paradox can be resolved if one assumes that such 'anionic protection' is weakened or even absent during the early stages of the ion formation process, and becomes only fully effective once the salt is formed.

The constitution of $\mathbf{2 a}\left[\mathrm{AlCl}_{4}\right]$ was confirmed by a singlecrystal X-ray diffraction study (see Table 1 for selected distances and angles). The crystal is composed of separated phosphenium cations and tetrachloroaluminate anions. Two chlorine atoms in each anion exhibit intermolecular contacts to the phosphorus atoms in adjacent cations $(\mathrm{P}-\mathrm{Cl} 3.2188(3)$ and $3.2408(3) \AA$ ) that are distinctly shorter than the sum of vander-Waals radii $\left(3.72 \AA^{16}\right)$ and cause the formation of onedimensional stacks of alternating anions and cations parallel to the crystallographic b-axis (Figure 1).

Figure 1. Representation of the molecular structure of a cation and two adjacent anions (the extra anion belongs to an adjacent ion pair was included to illustrate the intermolecular association) in crystalline $\mathbf{2} \mathrm{a}\left[\mathrm{AlCl}_{4}\right]$. Thermal ellipsoids were drawn at the $50 \%$ probability level and hydrogen atoms were omitted for clarity. Selected metric parameters are listed in Table 3. 


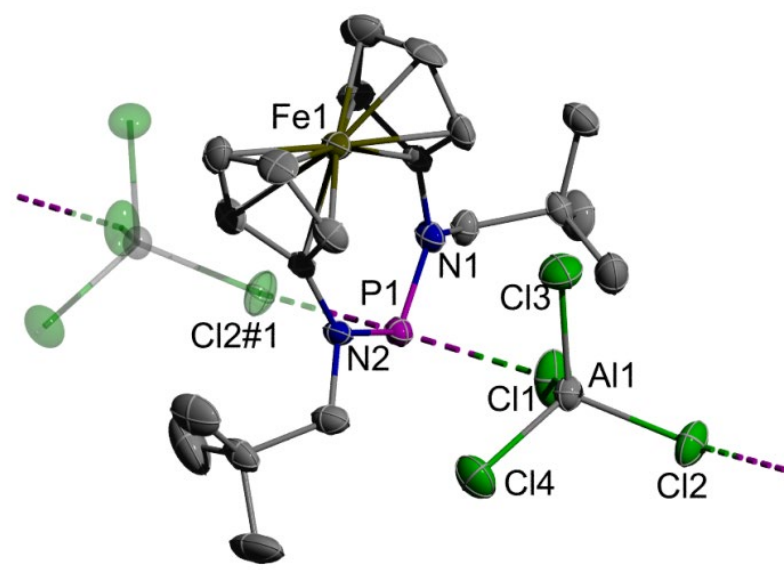

Table 1. Selected intramolecular distances (in $\AA$ ) and angles (in ${ }^{\circ}$ ) for $2 \mathrm{a}\left[\mathrm{AlCl}_{4}\right]$ and complexes $8 \mathrm{a}$,b.

\begin{tabular}{|c|c|c|c|}
\hline & $\mathbf{2} \mathbf{a}\left[\mathrm{AlCl}_{4}\right]$ & $8 \mathbf{a}$ & $8 \mathbf{b}$ \\
\hline $\mathrm{P}-\mathrm{N}$ & $\begin{array}{l}1.619(3) \\
1.628(3)\end{array}$ & $\begin{array}{l}1.713(2) \\
1.714(2)\end{array}$ & $\begin{array}{l}1.686(6) \\
1.698(5)\end{array}$ \\
\hline $\mathrm{N}-\mathrm{C}(\mathrm{Cp})$ & $\begin{array}{l}1.437(5) \\
1.442(5)\end{array}$ & $\begin{array}{l}1.420(4) \\
1.427(4)\end{array}$ & $\begin{array}{l}1.429(9) \\
1.456(9)\end{array}$ \\
\hline $\mathrm{Fe}-\mathrm{Cp}_{\text {cent }}{ }^{\text {a) }}$ & $\begin{array}{l}1.625(3) \\
1.629(3)\end{array}$ & $\begin{array}{l}1.648(3) \\
1.653(3)\end{array}$ & $\begin{array}{l}1.640(6) \\
1.649(6)\end{array}$ \\
\hline $\mathrm{Mn}-\mathrm{P}$ & & $2.1198(9)$ & $2.109(2)$ \\
\hline $\mathrm{Mn}-\mathrm{C}(\mathrm{CO})$ & & $\begin{array}{l}1.787(4) \\
1.816(4) \\
1.831(4) \\
1.851(3)\end{array}$ & $\begin{array}{l}1.774(10) \\
1.809(9) \\
1.819(9) \\
1.825(10)\end{array}$ \\
\hline $\mathrm{Al}-\mathrm{Cl}$ & $\begin{array}{l}2.1233(16) \\
2.1300(16) \\
2.131(2) \\
2.134(2)\end{array}$ & & \\
\hline $\mathrm{N}-\mathrm{P}-\mathrm{N}$ & $111.3(2)^{\circ}$ & $108.54(12)$ & $107.4(3)$ \\
\hline $\mathrm{Mn}-\mathrm{P}-\mathrm{N}$ & & $\begin{array}{l}122.66(9) \\
127.93(8)\end{array}$ & $\begin{array}{l}125.7(2) \\
126.6(2)\end{array}$ \\
\hline$\left.\Sigma(\mathrm{X}-\mathrm{P}-\mathrm{Y})^{\mathrm{b}}\right)$ & & $359.2(3)$ & $359.7(7)$ \\
\hline$\Sigma(\mathrm{X}-\mathrm{N}-\mathrm{Y})^{\mathrm{b})}$ & $\begin{array}{l}358.9(9) \\
359.3(9)\end{array}$ & $\begin{array}{l}348.8(6) \\
347.0(6)\end{array}$ & $\begin{array}{l}360.0(13) \\
359.6(11)\end{array}$ \\
\hline$\alpha^{c)}$ & $11.6(1)$ & $7.6(1)$ & $9.1(3)$ \\
\hline$\delta^{\mathrm{d})}$ & $9.1(1)$ & $-0.1(2)$ & $0.6(4)$ \\
\hline
\end{tabular}

a) $\mathrm{Cp}_{\text {cent }}=\mathrm{Cp}$-ring centroid; b) sum of bond angles at the phosphorus and nitrogen atoms, respectively; c) dihedral angle between the $\mathrm{C}-\mathrm{N}$ vectors in the ferrocene unit; d) tilt angle between the least-squares planes through the $\mathrm{Cp}$-rings in the ferrocene unit.

The ansa-bridge is characterized by short $\mathrm{P}-\mathrm{N}$ distances $(\mathrm{P}-$ N 1.619(3), 1.628(3) $\AA$ vs. values of 1.664(2) to 1.730(1) $\AA$ in the previously reported neutral NPN-[3]ferrocenophanes ${ }^{9,17}$ reflects) and planar coordination at the nitrogen atoms (sum of bond angles $358.9(9)$ and $\left.359.3(9)^{\circ}\right)$. The staggering of the Cp-rings (dihedral angle $\delta=9.1(1)^{\circ}$ ) results in a skewed, $C_{2}$ symmetric conformation of the ferrocenophane unit in which the nitrogen coordination planes deviate (torsional angle $17^{\circ}$ ) from the parallel alignment granting optimum NPN- $\pi$ conjugation. The inclination of the diaminophosphenium unit to retain such a planar conformation ${ }^{3}$ results further in an opening of the NPN valence angle $\left(111.3(2)^{\circ}\right.$ vs. $\approx 90^{\circ}$ in N- heterocyclic phosphenium ions $)^{3 \mathrm{~d}, 13}$ and a distinct spatial separation of the phosphorus and iron atoms ( $\left.\mathrm{Fe}^{\cdots} \mathrm{P} 3.625(3) \AA\right)$.

The structural features of the cation in $\mathbf{2} \mathbf{a}\left[\mathrm{AlCl}_{4}\right]$ epitomize typical characteristics of diaminophosphenium ions. ${ }^{3,13}$ The $\mathrm{P}-$ $\mathrm{N}$ bond shortening with respect to neutral NPN-[3]ferrocenophanes reflects the increased $\mathrm{P}-\mathrm{N} \pi$-bonding in the cation, the close match of the observed distance with a mean value of $1.615 \AA^{3 \mathrm{~d}}$ suggesting that the diaminophosphenium moiety is unperturbed by any conjugation interaction with the ferrocene unit. Moreover, the conformation of the NPN-bridge and the large $\mathrm{Fe} \cdots \mathrm{P}$ distance imply that direct back-bonding from the $\pi$-basic metal atom does not contribute to the stabilization of the remote electrophilic center in the bridging unit, which had been suggested for a [3] ferrocenophane-based plumbylene. ${ }^{7}$

The observation of intermolecular contacts at directions that are often close to perpendicular to the local NPN-plane is a common phenomenon in crystal structures of phosphenium ions and attributable to electrostatic stabilization of the highly electrophilic cations. ${ }^{3 \mathrm{~b}, 3 \mathrm{~d}, 13}$ However, intermolecular $\mathrm{P} \cdots \mathrm{Cl}$ interactions in diaminophosphenium tetrachloroaluminates and -gallates remain close to the sum of van-der-Waals radii $(\mathrm{P}-\mathrm{Cl}$ $>3.4 \AA),{ }^{3 \mathrm{~b}}$ whereas short contacts with similar distances as in $\mathbf{2} \mathbf{a}\left[\mathrm{AlCl}_{4}\right]$ are only known for strongly electrophilic cations obtained by formal exchange of one amino group by a substituent of weaker $\pi$-donating power. ${ }^{3 b, 3 d, 18}$ In this context, we regard both the short inter-ion contacts in crystalline $\mathbf{2} \mathbf{a}\left[\mathrm{AlCl}_{4}\right]$ and the observation of a relatively short $\mathrm{P}-\mathrm{Cl}$ distance in the chlorophosphine precursor $\mathbf{1 a}^{9}$ as structural indicators of an unusually high (for a cyclic diaminophosphenium ion) Lewis acidity of $\mathbf{2 a}^{+}$. Enhanced electrophilicity with respect to conventional $\mathrm{N}$-heterocyclic derivatives was also observed for ferrocenophane-based carbenes and is presumably attributable to the increased bond angle enforced by the geometrical constraints of the ferrocenophane skeleton. ${ }^{5 c, d}$ It should be noted, however, that the electron withdrawing power of the cation causes hardly any imbalance between the distances of 'coordinating' (2.123(2), 2.130(2) $\AA$ ) and 'free' (2.131(2), 2.134(2) $\AA$ ) $\mathrm{Al}-\mathrm{Cl}$ bonds, all of which remain essentially indistinguishable within experimental error. ${ }^{19}$

In order to delve further into the electronic interaction between the ferrocene and diaminophosphenium moieties in cation $\mathbf{2 a}^{+}$and assess its Lewis-acidity relative to other phosphenium cations, we performed a computational study. An initial evaluation of the performance of different computational approaches disclosed that the calculated distance between the centroids of the $\mathrm{Cp}$ rings in ferrocene is highly sensitive to the applied functional and basis set (Table S2, Supporting Information). The best match between computed and experimental structures was obtained at the $\omega \mathrm{B} 97 \mathrm{X}-\mathrm{D} / 6$ $311+\mathrm{G}^{* *}$ level, which was then employed for optimizing the molecular structures of the isolated cations $\mathbf{2 a}^{+}$and $\mathbf{2} \mathbf{c}^{+}$(with $N$-Me instead of $N$-neo-pentyl substituents) and the ion pairs $\mathbf{2 a}\left[\mathrm{AlCl}_{4}\right]$ and $\mathbf{2} \mathbf{c}\left[\mathrm{AlCl}_{4}\right]$, respectively. The calculated structural parameters of isolated $\mathbf{2 a}^{+}$and the ion pair $\mathbf{2} \mathbf{a}\left[\mathrm{AlCl}_{4}\right]$ obtained at this level displayed only minor differences and are in good agreement with the X-ray diffraction data. Moreover, Bader analysis of the electron density of the ion pair $\mathbf{2 a}\left[\mathrm{AlCl}_{4}\right]$ disclosed negligible electron densities at all bond critical points between cation and anion (see Figure S19 ${ }^{37}$ ), and we conclude that both ions are electronically sufficiently separated to allow further analysis of the electronic situation in the ferrocenyl-phosphenium unit under neglect of the anion. 
Our approach started with an analysis of electron densities resulting from restricted DFT calculations on $\mathbf{2 a}^{+}$and model cation $2 \mathrm{c}^{+}$at the $\omega \mathrm{B} 97 \mathrm{X}-\mathrm{D} / 6-311+\mathrm{G}^{* *}$ level of theory. Inspection of the frontier Kohn-Sham (KS) orbitals allowed us to identify the KS-HOMO of $\mathbf{2 a}^{+}$as a metal-centered MO with predominant $3 \mathrm{~d}$ character, and the KS-LUMO as the P,Ncentered $\pi_{3}{ }^{*}$-MO of the heteroallylic NPN-unit. While the KSLUMO has thus the same characteristics as in all diaminophospheniums, ${ }^{3} \mathrm{KS}$-orbitals with predominant $\mathrm{n}_{-}(\mathrm{N})$ and $\mathrm{n}(\mathrm{P})$ character, which commonly make the KS-HOMO and KSHOMO-1 in these species, ${ }^{3}$ are in case of $\mathbf{2 a}^{+}$located by 2.85 $\mathrm{eV}(\mathrm{n}-(\mathrm{N}), \mathrm{KS}-\mathrm{HOMO}-9)$ and $3.65 \mathrm{eV}$ (n(P), KS-HOMO-14) below the KS-HOMO (Table S4). The remaining closely spaced KS-Orbitals between HOMO and the $\mathrm{n}_{-}(\mathrm{N})$ orbitals are mixtures of Fe d-orbitals and cyclopentadienyl $\pi$-orbitals, and their ordering depends strongly on the level of theory applied. The results obtained on $\mathbf{2 c}^{+}$are similar and are given in Table S4.

The existence of energetically high-lying ferrocene-centered MOs in $\mathbf{2 a}^{+}$cuts down the energy gap between the electronic ground state and excited states and is expected to render both excited singlet and triplet states more easily accessible. In accord with this assumption, we found that $\mathbf{2 a}^{+}$and $\mathbf{2} \mathbf{c}^{+}$exhibit both distinctly lower singlet-triplet excitation energies $\left(\Delta E_{\mathrm{S} \rightarrow \mathrm{T}}\right.$ $\left.=25.4\left(\mathbf{2 a}^{+}\right), 38.3\left(\mathbf{2 c}^{+}\right) \mathrm{kcal} / \mathrm{mol}\right)$ and optical transition energies (see further below) than conventional $\mathrm{N}$-heterocyclic phosphenium ions (e.g. $\Delta E_{\mathrm{S} \rightarrow \mathrm{T}}=53.5 \mathrm{kcal} / \mathrm{mol}$ for $1,3-$ dimethyl-1,3,2-diazaphospholenium $\mathbf{5}^{+}$shown in Scheme 2). On the other hand, broken-symmetry approaches to the calculation of the DFT density of model cation $\mathbf{2 c}^{+}$converged to the restricted KS-solution, suggesting a closed-shell ground state. This was also confirmed by $\operatorname{CASSCF}(2,2) / 6-31 G^{*}$ calculations on $\mathbf{2 c}^{+}$using the $b_{1}$-symmetrical ferrocenium-based HOMO-2 and the phosphorus based LUMO from the HF/6$31 \mathrm{G}^{*}$ wavefunction (see Table S4) in the active space, which showed the predominant $(c=0.999)$ involvement of the HF determinant in the wavefunction. Further CASSCF calculations with more $b_{1}$ and even a pair of $a_{2}$ orbitals gave no indication that alternative electron configurations, like a 'ferrocenium-phosphinyl radical' resonance structure resulting from promotion of one electron from the Fe-centered HOMO into the phosphenium-centered LUMO, contribute significantly to the electronic ground state (see Table S5). We conclude therefore that the ferrocenophane-based phosphenium cations in their electronic ground state can be represented as closed-shell species with 'ferrocene-phosphenium ion' character and a formal $\mathrm{Fe}(\mathrm{II})$ oxidation state. This description is also in accord with the outcome of natural population analyses, which imply that the positive charge is centred on the NPN unit and not, as in a species like $\mathrm{fc}^{\prime}\left(\mathrm{P}^{t} \mathrm{Bu}\right)_{2} \mathrm{BMes}^{+\bullet},{ }^{20}$ delocalized between the iron and an adjacent phosphorus atom.

To assess the stabilization of $\mathbf{2 \mathbf { a } ^ { + }}$ and model cation $\mathbf{2} \mathbf{c}^{+}$with respect to other types of diaminophosphenium ions $\left(4^{+}\right.$to $\left.7^{+}\right)$ and parent $\mathrm{PH}_{2}^{+}$as a common standard, we evaluated the energies of isodesmic hydride transfer reactions (Scheme 2, all calculations at the $\omega$ B97X-D/6-311+G** level, gas phase). ${ }^{21}$

Scheme 2. Energies (in kcal mol-1) of isodesmic hydride transfer reactions between diaminophosphines and $\mathrm{PH}_{2}{ }^{+}$ calculated at the $\omega B 97 X-D / 6-311+G * *$ level of theory.
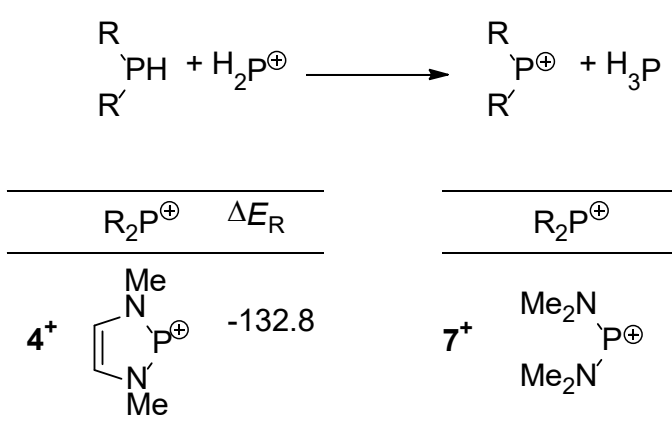

\begin{tabular}{ccc}
\hline $\mathrm{R}_{2} \mathrm{P}^{\oplus}$ & $\Delta E_{\mathrm{R}}$ \\
$7^{+}$ & $\mathrm{Me}_{2}{ }^{\mathrm{N}}{ }_{{ }^{\prime} \mathrm{P} \oplus}-107.6$ \\
$\mathrm{Me}_{2} \mathrm{~N}^{\prime}$ &
\end{tabular}<smiles>CN1CCN(C)P1[Te]</smiles>

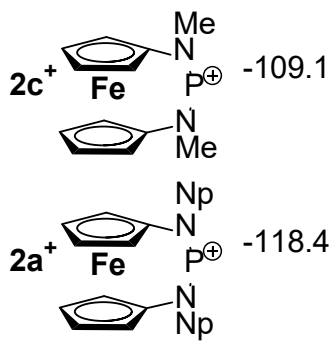

The results indicate that formal exchange of the bridging ethylene unit in $\mathbf{5}^{+}$by a ferrocene moiety destabilizes cation $2 \mathbf{c}^{+}$by $8.2 \mathrm{kcal} \mathrm{mol}^{-1}$, which is close to the $9.7 \mathrm{kcal} \mathrm{mol}^{-1}$ relative destabilization of the acyclic cation $7^{+}$. Since the Nsubstituents in all three species exhibit similar electronic characteristics, we relate the lower cation stabilization in $\mathbf{2}^{+}$and $7^{+}$ at least in part to the opening of the NPN angle (from $94.9^{\circ}$ in $\mathbf{5}^{+}$to $111.2^{\circ}$ and $109.8^{\circ}$ in $\mathbf{2 c ^ { + }}$ and $7^{+}$), which is known to have an adverse effect on the ground state stability of phosphenium ions. $^{22}$ The impact of these changes trails behind that of cyclic $\pi$-delocalization, which renders cation $4^{+}$more stabilized than $\mathbf{5}^{+}$by $15.5 \mathrm{kcal} \mathrm{mol}^{-1}$, but matches that of the inductive effects reflected in the $9.3 \mathrm{kcal} \mathrm{mol}^{-1}$ extra stabilization upon formal replacement of the $N$-Me substituents of $2 \mathbf{c}^{+}$by more electron releasing neo-pentyl groups in $\mathbf{2} \mathbf{a}^{+}$. In total, the trends in calculated hydride transfer energies endorse that ferrocenophanebased diaminophosphenium cations exhibit similar or even slightly lower stabilization than acyclic phosphenium ions with comparable peripheral substituents.

The deep red color of $\mathbf{2} \mathbf{a}\left[\mathrm{E}_{\mathrm{x}} \mathrm{Cl}_{3 \mathrm{x}+1}\right](\mathrm{E}=\mathrm{Al}, \mathrm{Ga})$, which contrasts the yellow appearance of known diaminoferrocenes (including precursor [3]ferrocenophane 1a), can be traced to a broad absorption in the visible region $\left(\lambda_{\max }=518 \mathrm{~nm}\right)$. The marked red-shift of this band compared to the absorptions of other diaminophosphenium ions (which generally lie outside the visible region $^{23}$ ) gives a first hint that electronic communication between the ferrocene and phosphenium fragments of $\mathbf{2 a}^{+}$, even if it is absent in the electronic ground state, may play a role in the electron excitation process. Confirmation of this hypothesis comes from a TD-DFT calculation, which predicts that the first transition in the electronic spectrum of $\mathbf{2 \mathbf { a } ^ { + }}$ (496 $\mathrm{nm}$ ) occurs at much larger wavelength (lower energy) than in case of $\mathbf{5}^{+}(259 \mathrm{~nm})$ and is not attributable to an $n-\pi^{*}$ transition as usual, but rather to an excitation from the metal-centered KS-HOMO into the NPN-centered KS-LUMO. Although this transition exhibits MLCT character, the oscillator strength is small. Further transitions involving KS-orbitals close to the frontier orbitals give rise to absorptions at slightly shorter wavelengths with even lower intensities. A transition exhibiting $n-\pi^{*}$ character does not appear among the ten lowest energy excitations, which is not surprising since the $n_{P}$-orbital is KS-HOMO-14. Calculations on a contact ion pair $\mathbf{2 a}\left[\mathrm{GaCl}_{4}\right]$ 
(using the PCM solvation model with solvent acetonitrile) reveal minor interactions between ions, which reshuffle the closely spaced excited states and induce a slight blue shift and an overall broadening of the observable absorption band.

Besides the free phosphenium ions, also their transition metal complexes raised considerable interest because of the analogy of these species to Fischer-type carbene complexes. ${ }^{3}$ While our attempts to prepare cationic complexes of $\mathbf{2 \mathbf { a } ^ { + }}$ remained as yet unsuccessful, we succeeded in obtaining neutral species 8a,b through metathesis of ferrocenophanes 1a,b with $\mathrm{Na}\left[\mathrm{Mn}(\mathrm{CO})_{5}\right]$ in ethereal solution (Scheme 3). Work-up afforded both species as deep red, crystalline, air and moisture sensitive products that were characterized by analytical and spectral data as well as single-crystal X-ray diffraction studies. The isolated solid samples are thermally stable at ambient temperature, but decompose eventually in solution. The ${ }^{31} \mathrm{P}$ NMR spectra of both compounds reveal broadened resonances at chemical shifts $\left(\delta^{31} \mathrm{P} 320(\mathbf{8 a}), 290(\mathbf{8 b})\right)$ exceeding that of free cation $\mathbf{2 \mathbf { a } ^ { + }}$. A similar line broadening, which is attributable to unresolved spin coupling of the ${ }^{31} \mathrm{P}$ nuclear spin with the quadrupolar ${ }^{55} \mathrm{Mn}$ nucleus ( $100 \%$ nat. abundance, $\left.I=5 / 2\right)$, and a positive coordination shift were previously observed for complexes $9^{24}$ and $\mathbf{1 0}{ }^{25}$ (Chart 3) and may be considered typical features of phosphenium complexes of manganese. A species featuring a broad ${ }^{31} \mathrm{P}$ NMR signal at $350 \mathrm{ppm}$ was also formed in the reaction of $1 \mathrm{a}$ with $\mathrm{Na}\left[\mathrm{Co}(\mathrm{CO})_{4}\right]$ and assigned as a neutral phosphenium- $\mathrm{Co}(\mathrm{CO})_{3}$ complex, ${ }^{26}$ but evaded all attempts toward isolation and further characterization by undergoing slow decomposition in solution.

Scheme 3. Formation of [3]ferrocenophane-based neutral diaminophosphenium complexes $\left(\mathrm{R}=\right.$ neo- $\mathrm{C}_{5} \mathrm{H}_{11}(1 \mathrm{a}, 8 \mathrm{a})$, $\mathrm{Me}_{3} \mathrm{Si}$ (1b, 8b), X = Cl (1a), Br (1b)).

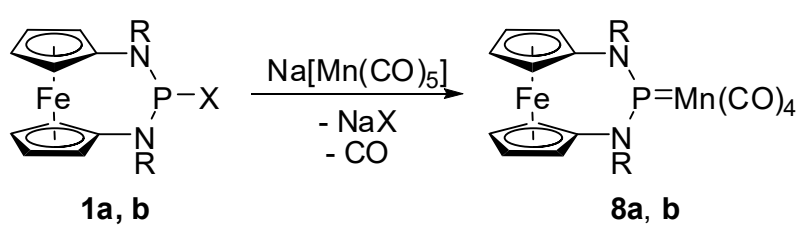

Chart 3. Molecular structures of 9, 10.

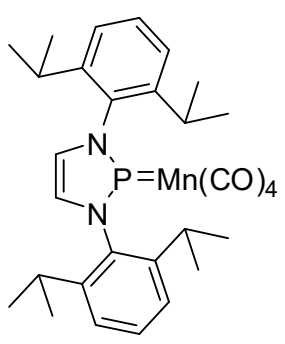

9

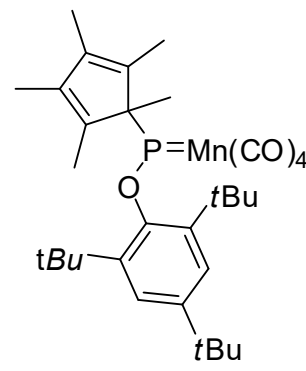

10
The molecular structures of $\mathbf{8 a}, \mathbf{b}$ in the crystal (Figure 2 and Figure S1) are, apart from the presence of different $\mathrm{N}$ substituents, closely similar and exhibit eclipsed ferrocene units with slightly tilted Cp-rings (see Table 1). The atoms in the NPN-bridge and the Cp-centroids form an 'envelope'shaped array in which the phosphorus atom is dislocated out of the plane defined by the four remaining centers. This conformation contrasts the flat arrangement of the NPN-bridge in $\mathbf{2} \mathbf{a}\left[\mathrm{AlCl}_{4}\right]$, but compares well to the alignment of the ferrocenophane moiety in the neutral phosphines $\mathbf{1 a}, \mathbf{b},{ }^{9}$ even if the phosphenium complexes and phosphines are clearly distinguished by their pyramidal $(\mathbf{1 a}, \mathbf{b})$ or planar $(\mathbf{8 a}, \mathbf{b})$ coordination environment at the central phosphorus atom. The nitrogen atoms in the phosphenium complexes exhibit planar $(\mathbf{8 b}$, sum of bond angles $360^{\circ}$ ) or quasi-planar (8a, sum of bond angles around $348^{\circ}$ ) coordination, and the folded conformation of the ferrocenophane framework enforces a twisted orientation of the amino fragments relative to the NPN-plane with torsional angles between $70^{\circ}$ and $90^{\circ}$. The $\mathrm{P}-\mathrm{N}$ distances in 8a,b exceed those in $\mathbf{2} \mathbf{a}\left[\mathrm{AlCl}_{4}\right]$ and fall into the range observed for 1a,b ${ }^{9}$ and related NPN-[3]ferrocenophanes ${ }^{17}$ (1.664(2) to $1.730(1) \AA$ ). The short P-Mn distances $(2.109(2)$ and 2.110(1) $\AA$ ) and the attachment of the phosphenium unit to an equatorial site of the tbp-coordination sphere around the metal center match appropriate features of $\mathbf{9}$ and $\mathbf{1 0 .}$

Figure 2. Molecular structure of $\mathbf{8 a}$ in the crystal (left) and reduced plot (right, with carbonyl ligands and peripheral $t \mathrm{Bu}-$ moieties omitted for clarity) showing a side view of the molecule. Thermal ellipsoids were drawn at the $50 \%$ probability level and hydrogen atoms were omitted for clarity. Selected geometric parameters are listed in Table 1.

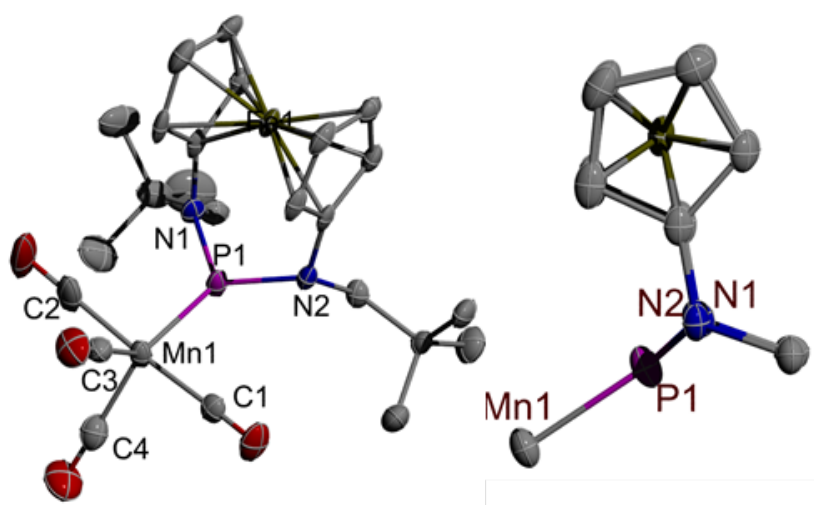

The observed structural features suggest depicting 8a,b as Fischer carbene-analogue phosphenium complexes ${ }^{3 \mathrm{c}}$ in which the electron deficiency at phosphorus is alleviated by formation of a $\mathrm{P}=\mathrm{M}$ double bonding interaction, while $\mathrm{P}, \mathrm{N}-\pi$ bonding remains negligible. A bonding situation of this type prevails frequently in metal complexes of acyclic phosphenium ions ${ }^{3}$ and further underlines the nature of cation $\mathbf{2 a}^{+}$as a strongly Lewis-acidic ligand. It has already been noted that the ordering of $\mathrm{P}-\mathrm{Mn}$ distances in these complexes (the shortest and longest bonds being found for $\mathbf{9}$ and $\mathbf{8 a}, \mathbf{b}$, respectively) does not necessarily correlate with the trend in $\pi$-acceptor capabilities of the phosphenium ligand, but may reflect other influences like the effects of rehybridization at the phosphorus atom. ${ }^{24}$ Specifically, the observed correlation between the increase in Mn-P distances and the opening of the NPN bond angles (9: N-P-N 89.0(2) $)^{\circ}$, 10: O-P-C 99.2(3) ${ }^{\circ}, \mathbf{8 a}, \mathbf{b}$ : N-P$\mathrm{N} 107.4(3)$ and $\left.108.54(12)^{\circ}\right)$ suggests that the bond lengthening may reflect the admixture of increasing $p$-character to the phosphorus-metal bond.

Bearing in mind that many ferrocene derivatives exhibit rich redox chemistry and are attractive targets for electrochemical studies, we also explored the electron transfer behavior of the newly synthesized ferrocenophane-phosphenium species using cyclic voltammetry. The cyclic voltammogram of $\mathbf{2 a}\left[\mathrm{AlCl}_{4}\right]$ displayed an irreversible reduction event $\left(E_{p}=-0.92(1) \mathrm{V}\right.$ vs. $\mathrm{Fc} / \mathrm{Fc}^{+}$), whereas electrochemical oxidation was not observable. The reduction of cation $\mathbf{2 a}^{+}$yields presumably a phos- 
phinyl radical, the instability of which was inferred in a previous study ${ }^{17}$ and would perfectly explain the irreversible behavior. Investigation of the phosphenium complexes $\mathbf{8 a}, \mathbf{b}$ gave only inconclusive and poorly reproducible results, presumably as a consequence of the decomposition of these species or their reaction products in solution.

\section{CONCLUSIONS}

A ferrocenophane-based diaminophosphenium ion and neutral metal complexes with such ligands were prepared from $P$ halogeno-substituted precursors via halide abstraction or metathesis with $\mathrm{Na}\left[\mathrm{Mn}(\mathrm{CO})_{5}\right]$, respectively. Experimental and computational evidence suggests that the free cation is best described as being composed of formally cationic diaminophosphenium and neutral ferrocene units, and behaves as a stronger Lewis-acid than other $\mathrm{N}$-heterocyclic phosphenium ions, presumably because of its widened N-P-N-angle. While these features highlight the similarity in electronic structure and bonding with isoelectronic and isosteric ferrocenophanebased tetrylenes, ${ }^{5-7}$ the phosphenium ion lacks the ability of its neutral analogues to undergo iron-centered oxidation, which we attribute to the increased positive charge. Electrochemical reduction was found to be irreversible and the postulated product - an elusive ferrocene-based phosphinyl radical evaded characterization. Binding to a $\mathrm{Mn}(\mathrm{CO})_{4}$-unit induces a trade-off of the $\mathrm{P}-\mathrm{N} \pi$-bonding for the formation of a metalphosphorus double bond. While this phenomenon is wellknown for phosphenium complexes with strongly electrophilic ligands, ${ }^{3}$ it is in the present case accompanied by a rather unprecedented structural change from a planar to a strongly folded conformation of the ferrocenophane bridge.

\section{EXPERIMENTAL SECTION}

All reactions were carried out under an atmosphere of inert argon and in flame-dried glassware. Solvents were dried as described ${ }^{27}$ and distilled prior to use. NMR spectra were recorded on Bruker AV250 or AV400 spectrometers, respectively. Chemical shifts in ${ }^{1} \mathrm{H}$ NMR spectra were referenced to TMS using the signals of the residual protons of the deuterated solvent $\left({ }^{1} \mathrm{H}, \delta\left(\mathrm{CD}_{2} \mathrm{Cl}_{2}\right)=5.34 ; \delta\left(\mathrm{C}_{6} \mathrm{D}_{6}\right)=\right.$ 7.15) as secondary reference. NMR Spectra of heteronuclei were referenced using the $\Xi$-scale ${ }^{28}$ with TMS $\left(\Xi=25.145020 \mathrm{MHz},{ }^{13} \mathrm{C} ; \Xi\right.$ $\left.=19.867187 \mathrm{MHz},{ }^{29} \mathrm{Si}\right), \mathrm{MeNO}_{2}\left(\Xi=10.136767 \mathrm{MHz},{ }^{15} \mathrm{~N}\right), 1.1 \mathrm{M}$ $\mathrm{Al}\left(\mathrm{NO}_{3}\right)_{3}\left(\Xi=26.056859 \mathrm{MHz},{ }^{27} \mathrm{Al}\right)$, and $85 \% \mathrm{H}_{3} \mathrm{PO}_{4}(\Xi=$ $40.480747 \mathrm{MHz},{ }^{31} \mathrm{P}$ ) as secondary references. FTIR spectra were recorded with a Thermo Scientific iS5 instrument equipped with an iD5 attenuated total reflectance (ATR) accessory. An Elementar Micro Cube elemental analyser was used for elemental analyses. [3]Ferrocenophanes 1a,b were prepared as described. ${ }^{9}$ Cyclic voltammetry studies on $0.1 \mathrm{mM}$ solutions of the samples in $\mathrm{CH}_{2} \mathrm{Cl}_{2}$ (dried over $\mathrm{CaH}_{2}$, distilled and stored over $3 \AA$ molecular sieves in argon atmosphere) containing $\left[n \mathrm{Bu}_{4} \mathrm{~N}\right]\left[\mathrm{PF}_{6}\right]$ (concentration $0.1 \mathrm{M}$ ) as conducting salt were carried out under inert argon atmosphere (in the case of 2c in a MBraun acrylic glovebox GB2202-C-VAC). The setup consisted of a three-electrode cell with a platinum disk as working electrode, a silver spiral as counter electrode, and a silver pseudo reference electrode. The potential was driven by a WaveDriver 20 bipotentiostat from Pine Research Instrumentation, and electrochemical data were recorded via AfterMath (Ver. 1.2.5966; Pine Instruments). The peak potentials of the redox processes were referenced using $\mathrm{Fc} / \mathrm{Fc}^{+}$.

Ferrocenophane-phosphenium salts $2 \mathbf{a}\left[\mathrm{ECl}_{4}\right](\mathrm{E}=\mathrm{Al}, \mathrm{Ga})$. $\mathrm{A}$ mixture of $1 \mathrm{a}(100 \mathrm{mg}, 238 \mathrm{~mol})$ and the appropriate metal trichloride ( $\mathrm{AlCl}_{3}: 30 \mathrm{mg}, 238 \mu \mathrm{mol} ; \mathrm{GaCl}_{3}: 40 \mathrm{mg}, 238 \mu \mathrm{mol}$ ) was mechanically agitated with a magnetic stir bar until the solid mixture adopted a homogeneous, dark red color. The crude products were obtained as oily or solid residue in $\approx 90 \%$ yield after evaporation of any volatile components. Single crystals of $\mathbf{2 a}\left[\mathrm{AlCl}_{4}\right]$ were obtained by dissolving the crude product in anhydrous $\mathrm{CH}_{2} \mathrm{Cl}_{2}(2 \mathrm{~mL})$, layering with pentane $(2 \mathrm{~mL})$ and allowing for mixing of the two solvents by diffusion. A small amount of red crystals that had formed overnight was collected after decantation of the mother liquor and cautiously dried in vacuum (yield $<5 \%$ ).

2a[AlCl 4 ]: ${ }^{1} \mathrm{H}$ NMR $\left(\mathrm{CD}_{2} \mathrm{Cl}_{2}, 400 \mathrm{MHz}, 303 \mathrm{~K}\right): \delta=4.72(\mathrm{~m}, 4 \mathrm{H}$, $\mathrm{Cp}), 4.46(\mathrm{~m}, 4 \mathrm{H}, \mathrm{Cp}), 3.85\left(\mathrm{~d}, 2 \mathrm{H},{ }^{3} J_{\mathrm{PH}}=15.8 \mathrm{~Hz}, \mathrm{CH}_{2}\right), 1.04$ (d, 18 $\left.\mathrm{H},{ }^{5} J_{\mathrm{PH}}=0.8 \mathrm{~Hz}, t \mathrm{Bu}\right) \cdot-{ }^{13} \mathrm{C}\left\{{ }^{1} \mathrm{H}\right\} \mathrm{NMR}\left(\mathrm{CD}_{2} \mathrm{Cl}_{2}, 101 \mathrm{MHz}, 303 \mathrm{~K}\right): \delta$ $=100.5\left(\mathrm{~d},{ }^{2} J_{\mathrm{PC}}=14.3 \mathrm{~Hz}, \mathrm{Cp}\right), 71.9(\mathrm{~s}, \mathrm{Cp}), 68.8\left(\mathrm{~d}, J_{\mathrm{CP}}=1.5 \mathrm{~Hz}\right.$, $\mathrm{Cp}), 66.7\left(\mathrm{~d},{ }^{2} J_{\mathrm{PC}}=36.2 \mathrm{~Hz}, \mathrm{CH}_{2}\right), 32.7\left(\mathrm{~d},{ }^{3} \mathrm{JPC}_{\mathrm{PC}}=3.5 \mathrm{~Hz}, \mathrm{NCC}\right), 27.7$ (d, $\left.{ }^{4} \mathrm{JPC}_{\mathrm{PC}}=1.9 \mathrm{~Hz}, \mathrm{CH}_{3}\right) .-{ }^{1} \mathrm{H},{ }^{15} \mathrm{~N}$ gs-HMBC $\left(\mathrm{CD}_{2} \mathrm{Cl}_{2}, 400 \mathrm{MHz}, 303\right.$ $\mathrm{K}): \delta^{15} \mathrm{~N}=-227\left(\mathrm{~d},{ }^{1} \mathrm{~J}_{\mathrm{PN}}=120 \mathrm{~Hz}\right) \cdot-{ }^{27} \mathrm{Al} \mathrm{NMR}\left(\mathrm{CD}_{2} \mathrm{Cl}_{2}, 104.3 \mathrm{MHz}\right.$, $303 \mathrm{~K}): \delta=103.7\left(\Delta v_{1 / 2}=16 \mathrm{~Hz}\right) .-{ }^{31} \mathrm{P}\left\{{ }^{1} \mathrm{H}\right\} \mathrm{NMR}\left(\mathrm{CD}_{2} \mathrm{Cl}_{2}, 163\right.$ $\mathrm{MHz}, 303 \mathrm{~K}): \delta=296.0$. The high sensitivity precluded obtaining a satisfactory elemental analysis and conclusive MS data, but the homogeneity was proven by spectroscopic data.

2a[ $\left[\mathrm{Ga}_{1.5} \mathrm{Cl}_{5.75}\right]:{ }^{1} \mathrm{H} \mathrm{NMR}\left(\mathrm{CD}_{2} \mathrm{Cl}_{2}, 400 \mathrm{MHz}, 303 \mathrm{~K}\right): \delta=4.71(\mathrm{~m}$, $4 \mathrm{H}, \mathrm{Cp}), 4.45$ (m, $4 \mathrm{H}, \mathrm{Cp}), 3.84$ (d, $\left.2 \mathrm{H},{ }^{3} \mathrm{~J}_{\mathrm{PH}}=15.8 \mathrm{~Hz}, \mathrm{CH}_{2}\right), 1.03$ $\left(\mathrm{d}, 18 \mathrm{H},{ }^{5} J_{\mathrm{PH}}=0.7 \mathrm{~Hz}, t \mathrm{Bu}\right) .-{ }^{13} \mathrm{C}\left\{{ }^{1} \mathrm{H}\right\}$ NMR $\left(\mathrm{CD}_{2} \mathrm{Cl}_{2}, 101 \mathrm{MHz}\right.$, $303 \mathrm{~K}): \delta=100.5\left(\mathrm{~d},{ }^{2} J_{\mathrm{PC}}=14.3 \mathrm{~Hz}, \mathrm{Cp}\right), 71.9(\mathrm{~s}, \mathrm{Cp}), 68.8\left(\mathrm{~d}, J_{\mathrm{CP}}=\right.$ $1.5 \mathrm{~Hz}, 66.7\left(\mathrm{~d},{ }^{2} J_{\mathrm{PC}}=36.2 \mathrm{~Hz}, \mathrm{CH}_{2}\right), 32.8\left(\mathrm{~d},{ }^{3} J_{\mathrm{PC}}=3.4 \mathrm{~Hz}, \mathrm{NCC}\right)$, $27.9\left(\mathrm{~d},{ }^{4} \mathrm{JPC}_{\mathrm{PC}}=1.9 \mathrm{~Hz}, \mathrm{CH}_{3}\right) .-{ }^{1} \mathrm{H},{ }^{15} \mathrm{~N}$ gs-HMBC $\left(\mathrm{CD}_{2} \mathrm{Cl}_{2}, 400 \mathrm{MHz}\right.$, $303 \mathrm{~K}): \delta^{15} \mathrm{~N}=-226.9\left(\mathrm{~d},{ }^{1} J_{\mathrm{PN}}=98 \mathrm{~Hz}\right) .{ }^{71} \mathrm{Ga}$ NMR $\left(\mathrm{CD}_{2} \mathrm{Cl}_{2}, 122\right.$ $\mathrm{MHz}, 303 \mathrm{~K}): \delta=248.3\left(\Delta v_{1 / 2}=2.3 \mathrm{kHz}\right) .-{ }^{31} \mathrm{P}\left\{{ }^{1} \mathrm{H}\right\} \mathrm{NMR}\left(\mathrm{CD}_{2} \mathrm{Cl}_{2}\right.$, $163 \mathrm{MHz}, 303 \mathrm{~K}$ ): $\delta=295.8$ (br). Anal. for $\mathrm{C}_{20} \mathrm{H}_{30} \mathrm{Cl}_{4} \mathrm{FeGaN}_{2} \mathrm{P}$ (596.82 $\left.\mathrm{g} \mathrm{mol}^{-1}\right)$ : calcd. C 40.25, H 5.07, N 4.69; found C 38.46, H $4.81, \mathrm{~N} 4.46 .{ }^{11}$ The high sensitivity precluded conclusive MS analysis.

Ferrocenophane-phosphenium-Mn(CO) ${ }_{4}$ complexes. A mixture of the appropriate P-halogeno-1,3,2-diazaphospha-[3]ferrocenophan (1a: $100 \mathrm{mg}, 238 \mu \mathrm{mol} ; \mathbf{1 b}: 100 \mathrm{mg}, 213 \mu \mathrm{mol})$ and $\mathrm{Na}\left[\mathrm{Mn}(\mathrm{CO})_{5}\right]$ (8a: $700 \mathrm{mg}, 321 \mu \mathrm{mol}$; 8b: $600 \mathrm{mg}, 275 \mu \mathrm{mol}$ ) was dissolved in anhydrous $\mathrm{Et}_{2} \mathrm{O}(10 \mathrm{~mL})$. After the evolution of $\mathrm{CO}$ (Caution! toxic!) had ceased, the mixture was stirred for additional $10 \mathrm{~min}$ and then evaporated to dryness. The residue was extracted with pentane $(5 \mathrm{~mL})$ and the formed suspension filtered through a layer of Celite.

Complex 8a: The filtrate was evaporated to a volume of $2 \mathrm{~mL}$ and the resulting solution stored at $-27^{\circ} \mathrm{C}$. Dark red crystals formed which were collected by filtration and dried in vacuum. Yield $92 \mathrm{mg}(70 \%)$; ${ }^{1} \mathrm{H}$ NMR $\left(\mathrm{C}_{6} \mathrm{D}_{6}, 400 \mathrm{MHz}, 303 \mathrm{~K}\right): \delta=3.98(\mathrm{~m}, 4 \mathrm{H}, \mathrm{Cp}), 3.84(\mathrm{~m}, 4$ $\mathrm{H}, \mathrm{Cp}), 3.2\left(\mathrm{~m}, 2 \mathrm{H}, \mathrm{CH}_{2}\right), 3.18\left(\mathrm{~m}, 2 \mathrm{H}, \mathrm{CH}_{2}\right), 0.92(\mathrm{~s}, 18 \mathrm{H}, t \mathrm{Bu})$. ${ }^{31} \mathrm{P}\left\{{ }^{1} \mathrm{H}\right\}$ NMR $\left(\mathrm{C}_{6} \mathrm{D}_{6}, 400 \mathrm{MHz}, 303 \mathrm{~K}\right): \delta=320$ (br). - IR (solid, $\nu \mathrm{CO}): \tilde{v}=2059(\mathrm{~m}), 1981(\mathrm{~m}), 1963$, (s) 1918 (s) $\mathrm{cm}^{-1}$. - Anal. for $\mathrm{C}_{24} \mathrm{H}_{30} \mathrm{FeMnN} \mathrm{O}_{2} \mathrm{P}$ : calcd. C 52.20, H 5.48, N 5.07; found C 51.82, H 5.57, N 5.01.

Complex 8b: The filtrate was evaporated to dryness and the residue dissolved in $\mathrm{MeCN}(2 \mathrm{~mL})$. Storage of the solution at $-27^{\circ} \mathrm{C}$ afforded $78 \mathrm{mg}$ (yield $65 \%$ ) of $9 \mathrm{~b}$ as ark red crystals. ${ }^{1} \mathrm{H}$ NMR $\left(\mathrm{C}_{6} \mathrm{D}_{6}, 400\right.$ $\mathrm{MHz}, 303 \mathrm{~K}$ ): $\delta=4.01$ (m, $2 \mathrm{H}, \mathrm{Cp}), 3.93$ (m, $2 \mathrm{H}, \mathrm{Cp}), 3.83$ (m, $2 \mathrm{H}$, $\mathrm{Cp}), 3.65$ (m, $2 \mathrm{H}, \mathrm{Cp}), 0.25$ (s, $18 \mathrm{H}, \mathrm{TMS}) .-{ }^{31} \mathrm{P}\left\{{ }^{1} \mathrm{H}\right\}$ NMR $\left(\mathrm{C}_{6} \mathrm{D}_{6}\right.$, $400 \mathrm{MHz}, 303 \mathrm{~K}): \delta=290$ (br). - IR (solid, $v$ CO): $\tilde{v}=2042$ (m), 1970 (m), 1932, (s) 1920 (s) $\mathrm{cm}^{-1}$. - Anal. for $\mathrm{C}_{20} \mathrm{H}_{26} \mathrm{FeMnN}_{2} \mathrm{O}_{4} \mathrm{PSi}_{2}$ : calcd. C 43.18, H 4.71, N 5.04; found: C 43.05, H 4.88, N 4.89.

Crystallography. X-ray diffraction studies were carried out using a Bruker Kappa Apex II diffractometer equipped with a Duo CCDdetector and a KRYO-FLEX cooling device with Mo- $K_{\alpha}$ radiation $(\lambda$ $=0.71073 \AA)$ at $T=150(2)\left(\mathbf{2 a}\left[\mathrm{AlCl}_{4}\right]\right)$ or $130(2) \mathrm{K}(\mathbf{8 a}, \mathbf{b})$, respectively. The structures were solved by direct methods (SHELXA ${ }^{29 a}$ ) and refined with a full-matrix least-squares scheme on $F^{2}$ (SHELXL$2014^{29 b}$ ). Semi-empirical absorption corrections were applied. Nonhydrogen atoms were refined anisotropically and hydrogen atoms with a riding model. CCDC-1942456 (2a[AlCl 4$]$ ), CCDC-1942458 (8a) and CCDC-1942457 (8b) contain the supplementary crystallographic data for this paper. This data can be obtained free of charge from the Cambridge Crystallographic Data Centre via www.ccdc.cam.ac.uk/data_request/cif.

Computational studies. All calculations were carried out with the Gaussian $09^{30}$ and MRCC $^{31}$ program packages. Full geometry optimization was performed for all molecules at $\omega \mathrm{B} 97 \mathrm{X}-\mathrm{D} / 6-311+\mathrm{G}^{* * 32}$ and B3LYP-D3/6-311+G**33 levels, followed by calculation of harmonic vibrational frequencies at the same levels to establish the nature of the 
stationary points obtained. Minima are characterized by only positive eigenvalues of the Hessian. Solvation effects were modelled by applying the implicit PCM (Polarizable Continuum Model) method ${ }^{34}$ during the geometry optimizations. Excitation energies of the cations were obtained from time-dependent DFT calculations at the B3LYP/6-311+G** level of theory, second-order algebraic diagrammatic construction $(\mathrm{ADC}(2)),{ }^{35}$ or second-order coupled-cluster singles and doubles $(\mathrm{CC} 2)^{36}$ approaches, respectively, using the $\omega \mathrm{B} 97 \mathrm{X}-\mathrm{D} / 6-311+\mathrm{G}^{* *}$ optimized molecular structures. The orbitals for complete active space calculations were chosen from the HF/6$31 \mathrm{G}^{*}$ orbitals (the shapes and energies are displayed in Table S4). The Multiwfn program ${ }^{37}$ was used to determine the bond critical points and the IQmol program ${ }^{38}$ for visualization of molecules and molecular orbitals.

\section{ASSOCIATED CONTENT}

\section{Supporting Information}

The Supporting Information is available free of charge on the ACS Publications website.

Crystallographic details for $[\mathbf{2 a}] \mathrm{AlCl}_{4}, \mathbf{8 a}, \mathbf{8 b}$; plots of NMR and IR spectra for [2a] $\mathrm{AlCl}_{4},[2 \mathbf{a}] \mathrm{Ga}_{1.5} \mathrm{Cl}_{5.75}, \mathbf{8 a}, \mathbf{8 b}$; UV-VIS spectrum of $[2 \mathbf{a}] \mathrm{AlCl}_{4}$; cyclic voltammetry studies of the reduction of [2a] $\mathrm{Ga}_{1.5} \mathrm{Cl}_{5.75}$; results of DFT and CASSCF calculations ( PDF)

\section{AUTHOR INFORMATION}

\section{Corresponding Author}

* E-mail: gudat@iac.uni-stuttgart.de.

\section{Notes}

The authors declare no competing financial interest.

\section{ACKNOWLEDGMENT}

The authors acknowledge financial support by the German Research Foundation (DFG) through grant no. GU 415/16-1, PI 353/10-1 and grant no OTKA NN 113772, and the EU-COST network CM1302 "Smart Inorganic Polymers" (SIPs). LN is grateful for the Alexander von Humboldt Foundation for the reinvitation grant. We further thank B. Förtsch for elemental analyses, and J. Trinkner and Dr. W. Frey (both Institute of Organic Chemistry, University of Stuttgart) for the recording of mass spectra and the collection of X-ray data sets, respectively.

\section{REFERENCES}

1 Fleming, S.; Lupton, M. K.; Jekot, K. Synthesis of a cyclic fluorodialkylaminophosphine and its coordination with boron acids. Formation of a unique dialkylaminophosphine cation. Inorg. Chem. 1972, 11, 2534-2540; (b) Maryanof, B. E.; Hutchins, R. O. Investigations of Doubly Connected Phosphorus Cations. Diaminophosphenium Ions from 2-R-2-Phospha-1,3-diazacyclohexanes. J. Org. Chem. 1972, 37, 3475-3580.

2 (a) Arduengo, A. J; Harlow, R. L.; Kline, M. A stable crystalline carbene. J. Am. Chem. Soc. 1991, 131, 361-363; (b) Igau, A.; Grützmacher, H.; Baceiredo, A.; Bertrand, G. Analogous $\alpha, \alpha^{\prime}$-biscarbenoid, triply bonded species: synthesis of a stable $\lambda^{3}$-phosphino carbene- $\lambda^{5}$-phosphaacetylene. J. Am. Chem. Soc. 1988, 110, 6463 6466.

3 Reviews: (a) Cowley, A. H.; Kemp, R. A. Synthesis and Reaction Chemistry of Stable Two-Coordinate Phosphorus Cations (Phosphenium Ions). Chem. Rev. 1985, 85, 367-382; (b) Gudat, D. Cationic Low Coordinated Phosphorus Compounds as Ligands: Some Recent Developments. Coord. Chem. Rev. 1997, 173, 71-106; (c) Rosenberg, L. Metal Complexes of Planar PR2 Ligands: Examining the Carbene Analogy. Coord. Chem. Rev. 2012, 256, 606-626; (d) Gudat, D. Low-Coordinate Main Group Compounds - Group 15. In Compreh. Inorg. Chem. II; Reedijk, J.; Poeppelmeier, K., Ed.; Elsevier: Oxford 2013, Vol 1, pp 587-621.
4 Reviews: (a) Haaf, M.; Schmedake, T. A.; West, R. Stable silylenes. Acc. Chem. Res. 2000, 33, 704-714; (b) Tokitoh, N.; Okazaki, R. Recent topics in the chemistry of heavier congeners of carbenes. Coord. Chem. Rev. 2000, 210, 251-277; (c) Gehrhus, B.; Lappert, M. F. Chemistry of thermally stable bis(amino)silylenes. $J$. Organomet. Chem. 2001, 617, 209-223; (d) Mizuhata, Y.; Sasamori, T.; Tokitoh, N. Stable heavier carbene analogures. Chem. Rev. 2009, 119, 3479-3511.

5 Carbenes: (a) Khramov, D. M.; Rosen, E. L.; Lynch, V. M.; Bielawski, C. W. Diaminocarbene [3] ferrocenophanes and Their Transition-Metal Complexes. Angew. Chem. Int. Ed. 2008, 47, $2267-$ 2270; (b) Siemeling, U.; Färber, C.; Bruhn, C. A stable crystalline Nheterocyclic carbene with a 1,1'-ferrocenediyl backbone. Chem. Commun. 2009, 98-100; (c) Siemeling, U. Färber, C. Leibold, M. Bruhn, C. Mücke, P. Winter, R. F. Sarkar, B. von Hopffgarten, M. Frenking, G. Six-Membered N-Heterocyclic Carbenes with a 1,1'Ferrocenediyl Backbone: Bulky Ligands with Strong Electron-Donor Capacity and Unusual Non-Innocent Character. Eur. J. Inorg. Chem. 2009, 4607-4612; (d) Siemeling, U.; Färber, C.; Bruhn, C.; Leibold, M.; Selent, D.; Baumann, W.; von Hopffgarten, M.; Goedecke, C.; Frenking, G. N-heterocyclic carbenes which readily add ammonia, carbon monoxide and other small molecules. Chem. Sci., 2010, 1, 697-704. (e) Siemeling, U. Singlet Carbenes Derived from Ferrocene and Closely Related Sandwich Complexes. Eur. J. Inorg. Chem. 2012, 3523-3536.

6 Germylenes and stannylenes: (a) Volk, J.; Correia Bicho, B. A.; Bruhn, C.; Siemeling, U. N-Heterocyclic germylenes and stannylenes of the type $\left[\mathrm{Fe}\left\{\left(\eta^{5}-\mathrm{C}_{5} \mathrm{H}_{4}\right) \mathrm{NR}\right\}_{2} \mathrm{E}\right]$ with bulky alkyl substituents. $Z$. Naturforsch. 2017, 72B, 785-794; (b) Oetzel, J.; Weyer, N.; Bruhn, C.; Leibold, M.; Gerke, B.; Pöttgen, R.; Maier, M.; Winter, R. F.; Holthausen, M. C.; Siemeling, U. Redox-Active N-Heterocyclic Germylenes and Stannylenes with a Ferrocene-1,1'-diyl Backbone. Chem. Eur. J. 2017, 23, 1187-1199; (c) Walz, F.; Moos, E.; Garnier, D.; Köppe, R.; Anson, C. E.; Breher, F. A Redox-switchable germylene and its ligating properties in selected transition metal complexes. Chem. Eur. J. 2017, 23, 1173-1186.

7 Plumbylenes: Guthardt, R.; Oetzel, J.; Schweizer, J. I.; Bruhn, C.; Langer, R.; Maurer, M.; Vicha, J.; Shestakova, P.; Holthausen, Max C.; Siemeling, U. Reactive Dimerization of an N-heterocyclic plumbylene: $\mathrm{C}-\mathrm{H}$ activation with $\mathrm{Pb}^{\mathrm{II}}$. Angew. Chem. Int. Ed. 2019, 58, 1387-1391.

8 Note that recently also isoelectronic [3]ferrocenophanes resulting from formal replacement of the nitrogen atoms in the bridge by phosphorus atoms were reported: (a) Kargin, D.; Kelemen, Z.; Krekić, K.; Maurer, M.; Bruhn, C.; Nyulászi, L.; Pietschnig, R. [3]Ferrocenophanes with the bisphosphanotetryl bridge: inorganic rings on the way to tetrylenes. Dalton Trans. 2016, 45, 2180-2189; (b) Kargin, D.; Krekić, K.; Pietschnig, R. Preparation and Molecular Structure of a Series of Bicyclic [3Ferrocenophanes Containing $\mathrm{Pb}_{2} \mathrm{P}_{2}$ Bridges. Z. Anorg. Allg. Chem. 2018, 644, 1051-1056; (c) Kargin, D.; Kelemen, Z.; Krekić, K.; Nyulászi, L.; Pietschnig, R. A Stabilized Bisphosphanylsilylene and Its Heavier Congeners. Chem. Eur. J. 2018, 24, 16774-16778; (d) Kargin, D.; Krekić, K.; Pietschnig, R. Preparation and Molecular Structure of a Cationic Bisplumbylene. Eur. J. Inorg. Chem. 2019, 1650-1656.

9 Weller, S.; Schlindwein, S. H.; Feil, C. M.; Kelemen, Z.; Buzsáki, D.; Nyulászi, L.; Isenberg, S.; Pietschnig, R.; Nieger, M.; Gudat, D. Controllable access to P-functional[3]ferrocenophane and [4]ferrocenophane frameworks. Dalton Trans. 2019, 48, 6236-6247.

10 Partial or complete spontaneous dissociation of $\mathrm{P}-\mathrm{X}$ bonds $(\mathrm{X}=$ halogen) is occasionally also observable when the cation receives additional stabilization from formation of a heteroaromatic $\pi$-electron system. The reader is referred to ref. $3 \mathrm{~d}$ for a detailed discussion of this topic, which has nonetheless no relevance for the chemistry described here.

11 The observed analytic composition suggests the presence of a $\mathrm{GaCl}_{3}$-rich phase with an empirical formula $\mathrm{C}_{20} \mathrm{H}_{30} \mathrm{Cl}_{5.75} \mathrm{FeGa}_{1.5} \mathrm{~N}_{2} \mathrm{P}$ resulting from the presence $\mathrm{GaCl}_{4}^{-}$and $\mathrm{Ga}_{2} \mathrm{Cl}_{7}{ }^{-}$anions in a 4:1 ratio.

12 For previous reports on analogous reactions, see: (a) Malavaud, C.; Boisdon, M.-T.; Charbonnel, Y.; Barrans, J. Haddad, M.; Dahan, F.; Legros, J.-P.; Lopez, L.; Boisdon, M.-T.; Barrans, J. Formation of 
stable cyclic dicoordinated phosphorus compounds by reaction of cyclophosphazanes with Lewis acids. Tetrahedron Lett. 1979, 5, 447450; (b) Dicoordinated Phosphorus Compounds: a novel 4.5disubstituted 1,2,4,3-triazaphosphole. X-Ray molecular structures of a $2-\mathrm{N}-\mathrm{BF}_{3}$ complex of 4.5-diisopropyl-1,2,4,3-triazaphosphole and of its tetramer. Conformation in the crystalline form and in solution. $J$. Chem. Soc. Perkin Trans. 2, 1992, 671-678; (c) Nitcheu, S. K.; Malavaud, C. Is the previously described N-phenyl 4,5-benzo 1,3,2diazaphosphole a dicoordinated phosphorus compound? Tetrahedron 1993, 49, 4651-4658. It is noteworthy that the calculated energy difference between $\mathbf{2 b A l C l} 4$ and $\mathbf{3 b}+\mathrm{Me}_{3} \mathrm{SiCl}$ was $0.01 \mathrm{kcal} / \mathrm{mol}$.

13 Gudat, D. Recent Developments in the Chemistry of $N$-Heterocyclic Phosphines. in Top. Heterocycl. Chem. 2010, 21, 63-102.

14 Gudat, D.; Nieger, M.; Niecke, E. Synthesis, structure, and chemical reactivity of a stable $\mathrm{C}_{5} \mathrm{Me}_{5}$-substituted phosphanylium ion: (pentamethylcyclopentadienyl)(t-butylamino)-phosphanylium tetrachloroaluminate. J. Chem. Soc. Dalton Trans. 1989, 693-700.

15 (a) Burford, N.; Losier, P.; Bakshi, P. K.; Cameron, T. S. Evidence for anionic protection of phosphenium centres. J. Chem. Soc. Dalton Trans. 1993, 201-202; (b) Jones, V. A.; Sripang, S.; Thornton-Pett, M.; Kee, T. P. Chiral phosphorus(III) triflates. On the nature of the phosphorus-oxygen interaction. J. Organomet. Chem. 1998, 567, 199-218.

16 Alvarez, S. A cartography of the van der Waals territories. Dalton Trans. 2013, 42, 8617-8636.

17 (a) Wrackmeyer, B.; Klimkina E. V.; Milius, W. 1,3,2Diazaphospha-[3]ferrocenophanes. Molecular Structures and Multinuclear Magnetic Resonance Studies. Z. Naturforsch., 2009, 64b, 1401-1412; (b) Wrackmeyer, B.; Klimkina E. V.; Milius, W. 1,3Bis(trimethylsilyl)-1,3,2-diazaphospha-[3]ferrocenophanes. Z. Anorg. Allg. Chem., 2010, 636, 784-794; (c) Isenberg, S.; Weller, S.; Kargin, D.; Valić, S.; Schwederski, B.; Kelemen, Z.; Bruhn, C.; Krekić, K.; Maurer, M.; Feil, C. M.; Nieger, M.; Gudat, D.; Nyulászi, L.; Pietschnig, R. Bis-[3]Ferrocenophanes with central $>$ E-E' $<$ bonds $(E$, $\left.\mathrm{E}^{\prime}=\mathrm{P}, \mathrm{SiH}\right)$ : Preparation, properties, and thermal activation. ChemistryOpen 2019, 8, 1235-1243.

18 (a) Hering, C.; Schulz, A.; Villinger, A. On the Synthesis and Reactivity of Highly Labile Pseudohalogen Phosphenium Ions. Inorg. Chem. 2013, 52, 5214-5225; (b) Hering, C.; Hertrich, M.; Schulz, A.; Villinger, A. Azidophosphenium Cations: Versatile Reagents in Inorganic Synthesis. Inorg. Chem. 2014, 53, 3880-3892.

19 Marked anion distortion was, however, observed in another case, see: Burford, N.; Cameron, T. S.; Clyburne, J. A. C.; Eichele, K.; Robertson, K. N.; Sereda, S.; Wasylishen, R. E.; Whitla, W. A. Nucleophilic Addition of $\mathrm{CH}, \mathrm{NH}$, and $\mathrm{OH}$ Bonds to the Phosphadiazonium Cation and Interpretation of ${ }^{31} \mathrm{P}$ Chemical Shifts at Dicoordinate Phosphorus Centers. Inorg. Chem. 1996, 35, 5460-5467.

20 Lik, A.; Kargin, D.; Isenberg, S.; Kelemen, Z.; Pietschnig, R.: Helten, H. PBP bridged [3]ferrocenophane: a bisphosphanylborane with a redox trigger. Chem. Commun. 2018, 54, 2471-2474.

21 (a) Schoeller, W. W.; Tubbesing, U. Relative cation versus anion stabilities of low coordinated P(III) $\pi$-bonded phosphorus compounds. J. Mol. Struct. (Theochem) 1995, 343, 49-55; (b) Gudat, D. Cation Stabilities, Electrophilicities, and "Carbene Analogue" Character of Low Coordinate Phosphorus Cations. Eur. J. Inorg. Chem. 1998, 1087-1094.

22 Schoeller, W. W. On the electronic structure of dihalogenophosphenium ions. J. Mol. Struct. (Theochem) 1998, 422, 285-291

23 Veith, M.; Bertsch, B.; Huch, V. Zur Element-StickstoffDoppelbindung in Kationen cyclischer Bis(amino)-phospha-, -arsa-, stiba- und -bismutane. Z. anorg. allg. Chem.1988, 659, 73-88.

24 Gediga, M.; Feil, C. M.; Schlindwein, S. H.; Bender, J.; Nieger, M.; Gudat, D. N-Heterocyclic Phosphenium Complex of Manganese: Synthesis and Catalytic Activity in Ammonia Borane Dehydrogenation. Chem. Eur. J. 2017, 23, 11560-11569.

25 Lang, H. Leise, M. Emmerich, C. [(2,4,6- $t \mathrm{Bu}_{3} \mathrm{C}_{6} \mathrm{H}_{2} \mathrm{O}\left({ }^{\circ} \mathrm{C}_{5} \mathrm{Me}_{5}\right] \mathrm{P}-$ $\mathrm{Mn}(\mathrm{CO})_{4}$ - stable $\lambda^{4}$-phosphanediyl complex with phosphorusmanganese multiple bond. J. Organomet. Chem. 1991, 418, C9-C13.

26 Burck, S.; Daniels, J.; Gans-Eichler, T.; Gudat, D.; Nättinen, K.; Nieger, M. $N$-Heterocyclic Phosphenium, Arsenium, and Stibenium Ions as Ligands in Transition Metal Complexes: A Comparative
Experimental and Computational Study. Z. Anorg. Allg. Chem. 2005, 631, 1403-1412.

27 Armarego W. L. F.; Perrin, D. D. Purification of laboratory chemicals, Butterworth-Heinemann, Oxford: 1997.

28 Harris, R. H.; Becher, E. D.; Cabral de Menezes, S. M.; Goodfellow R.; Granger, P. NMR Nomenclature: Nuclear Spin Properties and Conventions forChemical Shifts (IUPAC Recommendations 2001). Concepts Magn. Reson., 2002, 14, 326-346.

29 (a) Sheldrick, G. M. A short history of SHELX. Acta Crystallogr. 2008, A64, 112-122; (b) Sheldrick, G. M. Crystal structure refinement with SHELXL. Acta Crystallogr. 2015, C71, 38.

30 Frisch G. M. J.; and others, Gaussian 09, Revision E.01, Gaussian, Inc.: Wallingford, CT, 2009.

31 Mrcc, a quantum chemical program suite written by Kállay, M.; Nagy, P. R.; Rolik, Z.; Mester, D.; Samu, G.; Csontos, J.; Csóka, J.; Szabó, B. P.; Gyevi-Nagy, L.; Ladjánszki, I.; Szegedy, L.; Ladóczki, B.; Petrov, K.; Farkas, M.; Mezei, P. D.; Hégely, B. See also: Rolik, Z. Szegedy, L. Ladjánszki, I. Ladóczki, B. Kállay, M. J. Chem. Phys. 2013, 139, 094105, as well as www.mrcc.hu.

32 Chai J.-D.; Head-Gordon, M. Long-range corrected hybrid density functionals with damped atom-atom dispersion corrections, Phys. Chem. Chem. Phys., 2008, 10 6615-20.

33 Becke, A. D. Density-functional thermochemistry. III. The role of exact exchange, J. Chem. Phys. 1993, 98, 5648.

34 Miertuš, S.; Scrocco, E.; Tomasi, J. Electrostatic interaction of a solute with a continuum. A direct utilizaion of $\mathrm{AB}$ initio molecular potentials for the prevision of solvent effects. Chem. Phys. 1981, 55, 117.

35 Mester, D.; Nagy, P. R.; Kállay, M. Reduced-cost second-order algebraic-diagrammatic construction method for excitation energies and transition moments, J. Chem. Phys. 2018, 148, 094111.

36 Mester, D.; Nagy, P. R.; Kállay, M. Reduced-cost linearresponse CC2 method based on natural orbitals and natural auxiliary functions, J. Chem. Phys. 2017, 146, 194102.

$37 \mathrm{Lu}, \mathrm{T}$.; Chen, F. J. Comput. Chem. 2012, 33, 580-592.

38 Gilbert, A. T. B. IQmol Molecular Viewer. Available at: http://Iqmol.org (Accessed October, 2012) 


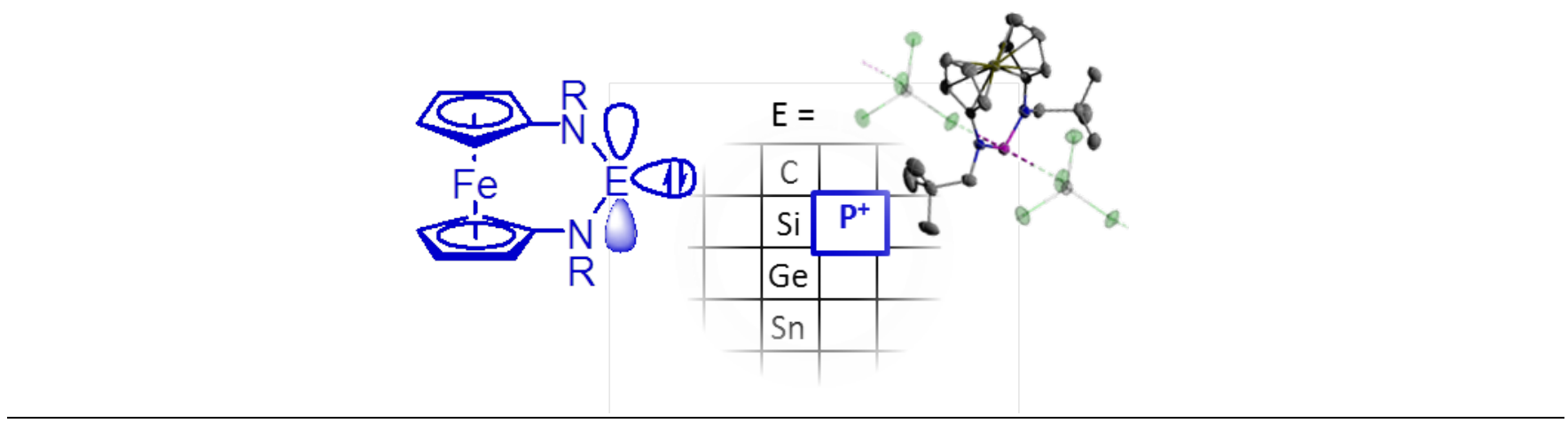

